\title{
DEVELOPMENT OF DIGITAL COMPETENCIES OF PRIMARY SCHOOL TEACHERS THROUGH BUILDING KNOWLEDGE AND SKILLS FOR WORKING WITH VISUAL PROGRAMMING ENVIRONMENT WITHIN MATH PROJECT WORK
}

\author{
Rumyana Y. Papancheva ${ }^{1}$, Rumyana I. Karadimitrova ${ }^{2}$ \\ ${ }^{1}$ University „Prof.Dr.Asen Zlatarov”, Faculty of Social Sciences, Burgas, Bulgaria \\ ${ }^{2}$ Plovdiv University „Paisii Hilendarski”, Faculty of Mathematics and Informatics, \\ Plovdiv, Bulgaria \\ papancheva@dgklaz.net; r.karadimitrova@hotmail.com
}

\section{Original Scientific Paper doi:10.5937/jouproman5-14495}

\begin{abstract}
The paper presents a review of the contemporary school, the digital generation and the need of teachers equipped with new knowledge and skills, in particular - basic programming skills. The last change of educational system in Bulgaria after the adoption of the new pre-school and general school education act is analysed. New primary school curricula and new standards for teacher's qualification were implemented. The new school subject "Computer modelling" is presented. Some experience of the authors from project-based work in mathematics with teachers and students is described. The aim is the formation of skills of programming by working within Scratch - visual environment for block-based coding. Some conclusions and ideas for future work are formulated.
\end{abstract}

Key word: "Computer modelling", contemporary school, digital generation, new knowledge.

\section{Introduction}

As early as the 19th and early 20th centuries, Dewey talk about the "new" school. Most of ideas and positions of those days are relevant today. The difference between traditional and the new school comes from the different attitude to thinking and the role of thinking into the learning process. According Dewey, the traditional school consider thinking as an incident into the process of learning, instead considering knowledge as an incident into the process of development of thinking. In the traditional school, the passive learning of knowledge prevails, and subsequently the consolidation of knowledge is done by memorizing and repeating (Dobrev at al, 1972).

Key standpoint, actual and today, is the school should be seen as part of the child's life, not as a preparation for his/her life in the future.

In his Pedagogic Creed, Dewey, says: „It conceives the school as a place where certain information is to be given, where certain lessons are to be learned, or where certain habits are to be formed. The value of these is conceived as lying largely in the remote future; the child must do these things for the sake of something else he is to do; they are mere preparation. As a result, they do not become a part of the life experience of the child and so are not truly educative." (Dewey, 1897) Problems and case studies with real life application should be studied at school. Topics with actuality on a personal, regional, national and global human level should be studied, and the students should be placed in an active research position.

\section{The New Dynamic Classroom}

Now we live in an information society dominated by the technologies and their rapid changes. Nowadays we need a "new" school to respond to the changes in the society and to the generation that enters and evolves into the education system. 
According classification of generations by Mark McCrindle generation $\mathrm{Z}$ are people born between 1995 and 2009, and the youngest /people born after 2010/ is generation "Alpha" (McCrindle, 2007). Generation $\mathrm{Z}$ is also called „Facebook Generation", digital natives, "Instant online" group, "dotcom" kids, i.e. Generation Alpha (children born after 2010) will be the most formally-educated generation in history. As the children of older (women have recently become mothers about 30 years old), wealthier parents and with more entertainment and technological options, it is likely that they will be the most materially-supplied generation of children ever. (McCrindle, 2010).

The digital generation evolves into a technology-rich environment, resulting in features such as visual-kinetic style of learning, clip-thinking, rapid thought, danger of superficial knowledge, etc.

Life in a digital world hides some dangers. The percentage of deviations in the behaviour of modern children is high and their manifestation is not only in the specialized institutions, but also in the mass school, respectively in the daily work of the pedagogue. (Dishkova, 2011). Various characteristics of deviant behaviour of students from the first to the eighth grade are revealed: Computer and Internet dependence; Lack of educational interest in computers and the Internet; Dominant interest in computer games filled with violence, aggression and cruelty. (Dishkova, 2008).

Desire for sharing is typical for the digital generation. Team work or working in pairs is the preferred form of organization of the learning process.

The need to use information technology at school comes naturally. 10-15 years ago, we used to talk about a modern classroom if the teacher uses a PowerPoint presentation. Now, we state that such a classroom is morally outdated. PowerPoint presentation gives only better visibilityand outlines the structure of the lesson. Because of the frontal form of the work and the lack of interactivity, the classical multimedia lesson set the students into the passive position of observers of the presented learning content.

The nature of the digital generation requires dynamics into the modern now-aday school. Under "dynamic" we understand:

- Opportunity for the teacher to use variety of technological tools.

- Pedagogical competencies for using different interactive methods.

- An environment that allows a rapid change of organizational form of work - individual work, work in pairs, team work, group work, and so on.

- Access to a variety of learning content in paper type and electronic form.

The realization of the dynamic classroom is a question of the parallel occurrence of many facts: A policy of the ministry of education that to be followed by all its structures; A vision of educational management that to be transformed into reality by the actions of the principals of the kindergartens and the schools, and the extremely important third factor - the qualified teachers, that to bring the work to its successful outcome - the formation of quality and lasting knowledge in students.

One of the key competences for teachers to successfully implement one dynamic classroom is their digital competence. According the European framework for Developing and Understanding Digital Competence (DIGCOMP, 2013) five areas are defined - information, communication, content creation, safety and problem solving. 
According data from the National Statistical Institute in Bulgaria in $2016 / 2017$ school year $49 \%$ of the teachers are over 50 years old. More than $80 \%$ of teachers are over 40 years old ${ }^{1}$. Considering that the majority of these teachers have completed their education more than 20 years ago, it is clear that they have not got a proper digital training at University level. The formation of digital competences takes the form of self-training by teachers, sharing good practice and ongoing training organized by the state and the educational institutions. The fact is that the level of technology integration into the learning process is far below what is desired. In general, teachers use presentations and / or an interactive whiteboard.

These data determine the need of continuous improvement of the qualification of the pedagogical specialists and especially the need of formation and constantly upgrade of their digital competences.

Forming and developing digital competencies should not be an end in itself. Work needs to be done to continuously expand and upgrade pedagogical and digital competences in unity with the formation of a wide range of knowledge and competences in the social sphere. It is nowa-days reality that there are a lot of socialeducational problems at school and family. It is a fact as well that these problems determinate appearance of more complicated problems, regarding education and whole growth of our children. These problems are even more frightening because they start from primary school and get more complicated during the years. Actually, if social-educational problems are not fixed in this early age, then may be too late. (Dishkova, 2015).

\section{The educational reform in Bulgaria}

The new law of pre-school and general school education has been in force since 1.08.2016. An important section into the law is the possibility of registering innovative schools and kindergartens, enabling the principals and the pedagogical teams to offer modern methods of work and pedagogical approaches that are adequate to the generation and the expectations of the society. The innovativeness is closely linked to the availability of qualified teachers. This is another key part of the law - the introduction of a system of credits for permanent qualification of the pedagogical specialists. The aim is the teachers to be motivated constantly to develop their professional knowledge and skills, including their digital competences.

The role of the universities is crucial. With offered masters programs, postgraduate qualifications and forms for the award of professional qualification degrees, the universities are basic unit into the system for qualification of the pedagogical specialists.

A new regulation on state requirements for acquiring the qualification "teacher" enters into force as of the school year 2017/2018. An emphasis into the document is the significant increase in the minimum number of hours for disciplines from Pedagogy of teaching. This change provides better opportunities for universities to prepare students for their professional realization into the pedagogical practice.

Changes in the law lead to changes in curricula and programs. To form algorithmic and critical thinking in students a new school subject is introduced Computer modelling. It will be studied from the third grade of the Primary school. ${ }^{2}$

\footnotetext{
${ }^{2}$ http://mon.bg/?h=downloadFile\&fileId=10948 Learning curricula on Computer Modelling for the $3^{\text {rd }}$ grade of the Primary School.
}

\footnotetext{
${ }^{1}$ http://nsi.bg/bg/content/ - National Statistical Institute in Bulgaria. Education and life-long learning. Teachingstaff. 
The training in Computer modelling at Primary school aims at mastering basic knowledge, skills and attitudes related to building digital literacy of students by creating computer models of known objects, processes and phenomena and experimenting with them.

The learning content for the third grade is structured in seven themes: Digital devices, Digital identity; Constructing consecutive actions; Constructing repetitive actions; Visual programming environment; Working with text and sound in visual programming environment; Into the world of the animation. Conditional operator are introduces at fourth grade. The projectbased approach in teaching and learning is implemented.

\section{Experimental work}

The rapid changes in society pose serious challenges to teachers, particularly the Primary school teachers. If he/she had to learn to make presentations $10-15$ years ago, now he/she is expected to be familiar with programming (albeit at a very basic level). This raises some questions - whether a person who does not have basic IT training can teach computer modelling and can form students' initial programming skills; whether all elementary school students will cope with the development of computer applications. Although in a simple form, the creation of computer applications requires programming. For this purpose, clear logical and algorithmic thinking is needed. Students have to create a program code through a set of commands and to execute it in a programming environment.

The experimental work is designed to form digital competencies that correspond with Area 3 - Content creation and Area 5 - Problem solving - from European framework mentioned above (DIGCOMP, 2013). The students - future teachers create mathematical content for the primary school in the form of a simple computer game. The aim is to form and upgrade their knowledge of programming - to understand the principles of programming, to understand what is behind the program. During the project work students innovating and creatively using technology. They produce multimedia resources to develop mathematical knowledge and skills of young students.

The aim of the study is the formation of knowledge for working with visual environment for programming and the upgrading students' knowledge of basic concepts of Informatics. For achieving the aim the following tasks are formulated:

1. Knowledge and skills for working with the visual environment for block-based programming Scratch to be formed.

2. Knowledge for successive operators to be developed.

3. Knowledge about computer cycles to be formed.

4. Knowledge about conditional operators to be formed

5. A system of computer games for improving math knowledge and skills of first grade students to be designed and developed.

The implementation of the assigned tasks is done by developing and conducting a project work entitled "Fun Mathematics".

The experimental work was carried out in the school year 2015/2016 with a group of 13 students, from the master program "Information technologies in the education 1st-4th grade", at the Faculty of Social Sciences, University "Prof. Dr. Asen Zlatarov" within the course "Visual Programming". Students have a basic knowledge of information technology. They have not studied programming and informatics. 10 of the students have worked as primary or kindergarten teachers for one or two years. 3 of students did not work as teachers. 
Students should develop a system of computer games on topics from mathematics content for the first grade of Primary School. The games must have been created in the Scratch environment and have the following features - a button to start the game, clear game rules, a clearly defined end-of-game condition, a game scoring system.

The environment $\mathrm{Scatch}^{3}$ is a MIT Media Lab project for developing of computer games, animations and interactive stories. The aim is to develop programming skills at an early age. The project was launched in 2005 and has become the world's most popular block visual programming environment. Currently, Scratch's site statistics show over 20 million shared projects. The interface of the program is intuitive, accessible in Bulgarian, the blocks of the different commands are grouped by type and have colour identification. The code is "written" by stacking blocks only by dragging and dropping. A preview screen is available.

Experimental work goes through three stages - establishing, forming and controlling

At the establishing stage, through a survey, it was found that none of the students had worked with Scratch. No one of the students has programming knowledge and therefore does not know how to create a computer game. Students are familiar with some concepts as "algorithm" and "computer program" from the course on "Information Technology at Primary School". Students do not have knowledge and skills to create a computer program. They are not familiar with terms as "sequential commands", "computer cycle", "conditional operators".

At the formative stage, 2 hours of lectures are held to familiarize students with Scratch - the block based visual programming environment. As a preparatory work with the students, two types of mathematics teaching materials for 1st grade are developed - a mathematics quiz (Figure 1) and an interactive multimedia application, which demonstrates the drawing of basic geometric figures, studied in the first grade - a square and a triangle (Figure 2). Working time for the two tasks is 5 academic hours.

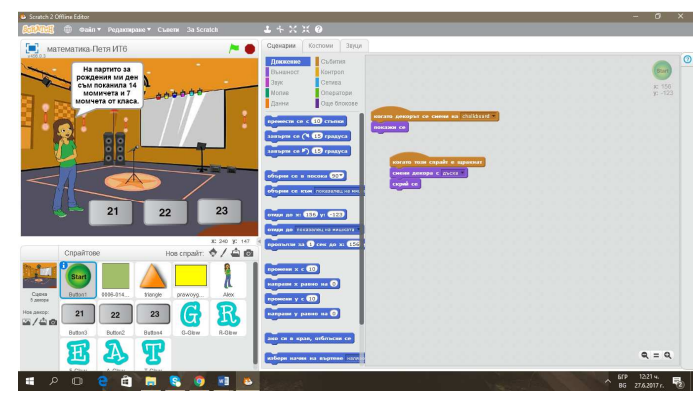

Figure 1. Math Quiz

The creation of math test builds knowledge and skills to work with sequential and conditional operators. By drawing geometric figures, knowledge and skills of computer cycles are formed.

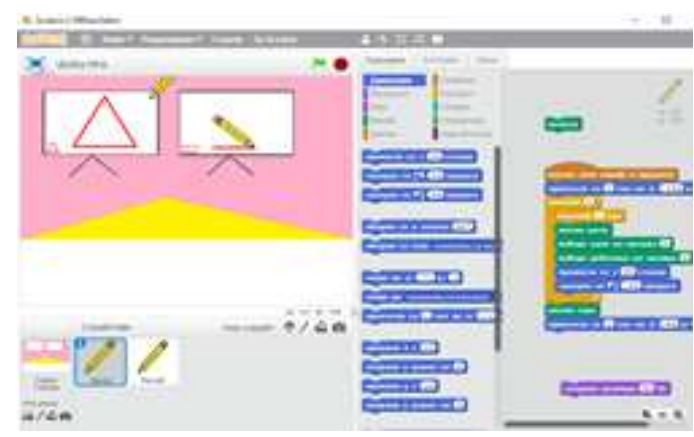

Figure2. Drawing triangles and squares.

The project work is set. Students work individually. Everyone designs and programs their own game. The implementation of the project is within 10 academic hours with guidance and consultancy from the lecturer, and 10 hours of independent work outside the university.

The project work itself has three stages organizational, operational and productive.

\footnotetext{
${ }^{3}$ https://scratch.mit.edu/ 
At the organizational stage, the authors develop the project and conduct the introductory training. At the operational stage, students work on the design, content, and programming of the game. At the productive stage a presentation of the final products of the project work is organized. Each student demonstrates their game, presents the rules and interface of the game. Screenshots of completed computer games are shown in Fig. 3 and Fig. 4.

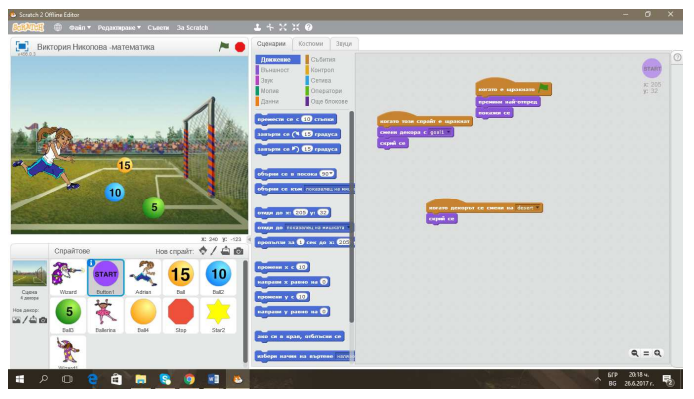

Figure3. Math football

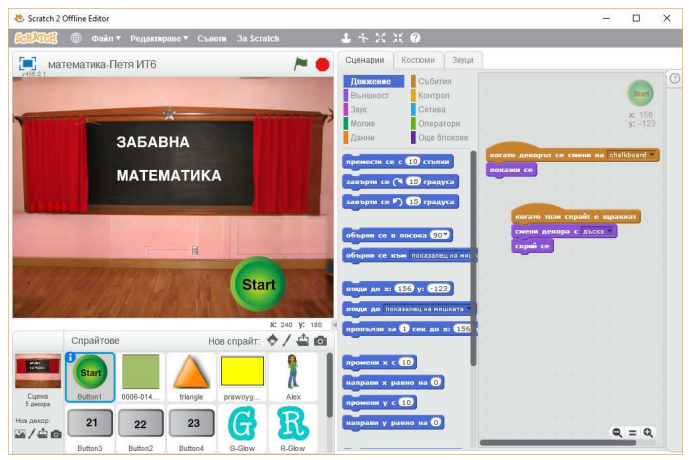

Figure4. Funny figures

The evaluation of the results of the conducted research is based on a 5-point scale with values from 0 to 4 . The value 0 means that the task is not completed, the value 4 - the task is completely fulfilled. 1 point - the student has worked but there's no running game. 2 points - student has worked but lacking some functionality or the game gives an error state. 3 points - the game works with minor notes on the functionality or logic of the game. On sodefined scale, the results of the students work are presented on the diagram from Figure 5.

It is clear that, with the exception of three students who have not worked on the assignment, everyone else has done well. 4 students have committed minor inaccuracies such as a design error or an easy-to-fix error in the program code. Six students have fully coped with the task.

Assesment of Students' Games

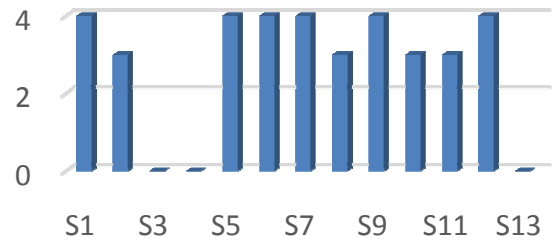

Figure5. Assessment of project works

In the current school year, the authors conducted a parallel experiment on a similar task with less complexity, but working with pupils from the fourth grade of Primary school. The project work "Students as Teachers" was carried out. As part of this work, students created animated dialogues between two characters where one character asks questions and the other responds. Questions and answers are from the learning content of the school subjects Mathematics, Literature, Man and Society and Man and Nature. The aim was to check the students' level of success when working with completely unfamiliar visual programming environment Scratch.

The experimental work took place in May 2017 with 20 students from the 4th grade of "Vasil Aprilov" Primary School, Burgas. Working time - 6 school hours. Within this short time, students became familiar with Scatch's programming environment. Working in 4 teams they created animated applications. A screenshot of the work of the mathematics team is shown on Figure 6. 


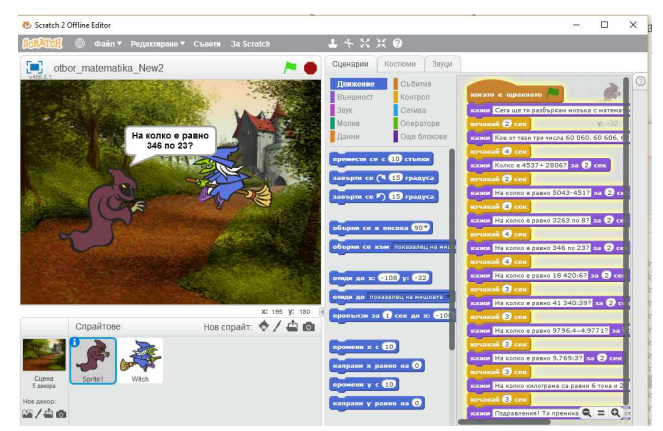

Figure6. Team work - "Math exam"

The additional experiment unambiguously shows that students are much more likely to be oriented in the programming environment than current and/or future teacher students. The relatively difficult matter - programming, commands, time management, text input, etc. is on the students ability level. Fourth-grade students are easily coping with the new knowledge.

\section{CONCLUSIONS}

Based on the research conducted some conclusions could be formulated:

1. There is a need for in-depth preparation of Primary School teachers to work with a visual environment to program and create computer applications with simple logic. Computer Modelling teachers have to pass an additional qualification - within a postgraduate or master's degree program. The aim of the training is the formation of basic knowledge about algorithm, computer program, information, etc., to be able to form these concepts and terms at propaedeutic level to third and fourth grade students.

2. Working with the block-based visual programming environment is within the capabilities of the Primary school teachers and students.

3. The project work is an extremely effective method in the formation of digital skills, as the learner has to pass all the way of creation of the final product. In the course of the project work, rich interdisciplinary relations are realized. By creating their comic books, students did serious study on subjects from Mathematics, Literature, Man and nature, and Man and society.

\section{PERSPECTIVES}

The described work with a small modification can be realized with students from third and fourth grade. They will develop a system of computer games in mathematics for first grade pupils. Thus, on the one hand, basic knowledge of programming will be formed, and on the other - pupils will be placed in the active position of computer game developers from developing the logic and rules of the game to designing, programming and implementing of the game.

\section{REFERENCE}

[1] Dewey, J., (1897). My Pedagogic Creed, School Journal, vol. 54 (3) p. 77-80.

[2] DIGCOMP (2013). Framework for Developing and Understanding Digital Competence in Europe - Author: Anusca Ferrari Editors: Yves Punie and Barbara N. Brečko.

[3] Dishkova, M., (2008). Deviantnoto povedenie u detsata kato pedagogicheski fenomen. Avtoreferatna disertatsia za prisazhdanena obrazovatelna i nauchnastepen „Doktor“ po nauchna spetsialnost „Teoria na vazpitanieto i didaktika“, shifar № 05.07.01, Sofia, s. 149.

[4] Dishkova, M., (2011). Neobhodi mostot spetsialna podgotovka na badeshtite spetsialisti - pedagozi za rabota $\mathrm{s}$ detsa $\mathrm{s}$ deviantno povedenie. Sbornik s nauchni statii „Pedagogic heskatasreda $v$ universiteta kato prostranstvo za profesionalno-lichnostno razvitiena badesh tia spetsialist ". Vtora kniga. Tom parvi. Gabrovo, 362-367.

[5] Dishkova, M., (2015). Cold war between teachers and parents. Sbornik nauchnoh trudov, Mezhdunarodnoy nauchnoprakticheskoy konferentsii: „Vzaimo deystvie organov vlasti, obshtestvennblh obaedineniyi obrazovatelnblh uchrezhdeniy po garmonizatsii эtno konfessionaly nblhimezh natsionaly nblh otnosheniy: 
regionalynbly aspect“, g. Kazany, Rossia, 90-92.

[6] Dobrev D., Ts. Tsonev, (1972). Vaprosi na problemnoto obuchenie $v$ nachalnoto uchilishte - sbornik, Narodna prosveta, Sofia.

[7] McCrindle, Mark, (2010). Top 7 Trends of the New Decade: 2010-2020, Culture scope, Vol. 93, 7-8.

\section{ACKNOWLEDGMENTS}

The article is part of a study of authors under project DN 05/8 14.12.2016, funded by the National Science Fund on ,Digital Competencies and Media Education at Preschool and Primary School Age “. 